\title{
The Opinions of Instructors Teaching Turkish to Foreigners about the Writing Skills of Syrian Students
}

\author{
Murat Şengül \\ Correspondence: Murat Şengül, Nevsehir Haci Bektas Veli University, Department of Turkish Language Education, \\ 50300 Nevsehir, Turkey
}

Received: July 3, 2015 Accepted: July 20, 2015 Online Published: July 29, 2015

doi:10.11114/jets.v3i5.928

URL: http://dx.doi.org/10.11114/jets.v3i5.928

\begin{abstract}
This study focuses on the difficulties experienced by the instructors while teaching writing skill to Arabians from Syria, and how these difficulties could be overcome. The study group of the research includes 11 instructors working in Turkish Teaching Centers (TTCs) of Cukurova University and Adana Science and Technology University. The data collected through the use of interview forms prepared by the researcher. After the interviews, content analysis was performed on the data collected. Following the content analysis, the data were analyzed by the researchers and grouped under certain titles and codes. Based on the content analysis, it is found that there is a lack of experts in teaching Turkish as a foreign language and materials particularly designed and developed for teaching Turkish writing are needed. Moreover, the teaching of suffixes, umlaut letters and conjunctions are problematic areas while teaching writing skills to Arabians from Syria. Suggestions have been put forward to overcome the difficulties reported by the instructors based on the findings of the study.
\end{abstract}

Keywords: Instructors, Syrian Arabians, teaching Turkish as a foreign language, writing education, writing skills

\section{Introduction}

People have established their relationships upon listening and speaking skills since they first started to communicate. From past to present, with the development of communicative ways and tools, writing and depending on writing, reading skills have made progress. This progress has changed the way we communicate positively. These four skills which support each other make up today's communication and language acquisition. Writing is a crucial skill because it gives students opportunities of arranging and enhancing knowledge, enlarging and expressing opinions in a planned way (Özbay, 2014). Writing is a long process in which students are expected to arrange their knowledge and sentences which are related to each other in a sequence according to grammar rules (Ungan, 2007). Writing is to convey feelings and opinions to letters. Writing is a psycho-motor skill in which the perceptual and motor sides are at high level (Barın, 2006). In other words, writing can be defined as the transfer of the communication onto a visual ground through the symbols. In the criteria of communication and language learning, writing is marking materials learned and heard for mind through symbols and reinforcing the input heard and making the input alive in brain. The most important effect and role of writing is that the language learned gives pleasure and sense of achievement just like a painting of an artist whose paints are still wet.

It can be said that the order of acquiring skills is listening, speaking, reading and writing in the second language acquisition. In the writing skill training, the last step of this natural and essential order, students are to use reading and speaking skills effectively in order to understand how much they learned from the information given and to evaluate the process. However, it is possible to claim that writing, writing is the most difficult skill among others for students and instructors.

Writing is a skill that requires more effort especially in Teaching Turkish to Foreigners, because this skill is the one in which mental process is used most actively. As reading, writing and speaking skills proceed in a desired way; training of writing skill becomes easier for student and instructor. However, the problems Arabian citizens encountered while learning to write in Turkish still keep priority to overcome for TTCs since no effective solutions exist to address these problems in the literature. The Arabic alphabet and components of Arabian culture including the phrases and idiomatic expressions that the Syrian students have before starting to learn Turkish as a foreign language makes training of writing in Turkish more difficult for them. It is a must to improve students' writing skill to give opportunity to use their 
own ideas and imagination in expressing and sensing the world as well as teaching them instructive writing (Göçer, 2010). Therefore, it is important for TTCs to help Syrian speakers of Arabic while they are learning to write in Turkish. Turkey has strengthened its position in the region in recent times, which contributes to the importance of knowing Turkish. Also, the number of quality universities in Turkey has increased. Both conditions have attracted more students from Africa and Middle East countries to Turkey. Over the last two years, particularly Syrian Arabian students have applied to TTCs in the cities such as Gaziantep and Adana which are close to the region in action to other TTCs in the big cities like İstanbul, Ankara and İzmir. The increase in the number of Arabian students coming from Syria in TTCs has dramatically attached much significance to the education given to the students speaking Arabic. In the following years, besides the expected increase in those numbers, teaching Turkish to students speaking Arabic will be the most important issue on the agenda for TTCs. Teaching Turkish to Arabian people immigrated to Turkey will help them to adapt to the daily life more rapidly. Moreover, students may teach Turkish to their families first and then to their social surroundings by social learning method. TTCs whose aim are to teach Turkish to foreigners in an ideal format will be the most important institute by taking coordinator-ship of other education foundations to accelerate orientation process of Syrian Arabians and to provide their participation to the education process immediately.

The negative events occurring recently in the neighboring countries of Turkey and the gloomy atmosphere due to these events have forced Syrian people to immigrate. Turkey, geopolitically the most important country in the region, has welcomed the people fleeing from the war and thousands of Syrian refugees, if not millions, have migrated to Turkey. In addition to the basic survival needs of these huge numbers of refugees such as water, food and shelter, communicating is a requirement for them to adapt to life in Turkey. Learning to communicate with the citizens of the country they live in will make the lives of Syrian Arabians much easier and also will accelerate their integration process. In the classes and the courses opened in the camps and in schools connected to MoNE (Ministry of National Education), basic Turkish education is given to students. This Turkish education is so important for the refugees in order to learn the Turkish culture, to adapt to the life in Turkey and minimize their feeling of foreignness by establishing a balance with their own culture and Turkish culture.

Writing which is an essential part of communication is also another important skill for Syrian Arabians to be learned for their survival in Turkey since their return to their country is difficult to foresee and they should achieve the integration into the life in Turkey. In this study, it is aimed to reach conclusions about the topic on the basis of opinions of the instructors working TTCs of Cukurova University and Adana Science and Technology University and to determine the problems experienced by Arabians from Syria while learning the writing skill based on the opinions of the instructors.

\section{Methodology}

In this qualitative study, content analysis was used to determine the problems of Syrian Arabian citizens in TTCs while teaching Turkish writing skill to them. According to Strauss and Corbin (1990), "qualitative research, method is one of the knowledge production processes to comprehend people's life-styles, stories, behaviors, besides organizational structure and social change" (as cited in Özdemir, 2011: 325). In quantitative research method, topic of a study is described with numbers, whereas in qualitative research method, the perceptions and events are presented profoundly in their natural environment with the qualitative data gathering techniques such as realistic and holistic observation, interview and document analysis (Yıldırım \& Şimşek, 2005). Qualitative research methods are used for not only physical events and behaviors, but also how people perceive these situations, events and acts and how this perception affects behaviors. In the study, it was benefited from interview form which is one of the qualitative research methods and content analysis was conducted on the data gathered from the interviews.

\subsection{Study Group}

The study group of this qualitative research includes 11 instructors working in Turkish Teaching Centers (TTCs) in Cukurova University and Adana Science and Technology University. In the group, there are two males and nine females. There were two master and nine doctoral students in terms of their educational status.

\subsection{Data Collection Tools}

The data in the study were collected with structured interview forms prepared by the researchers. The interview forms were redesigned with the experts' opinions in Nevsehir Haci Bektas Veli University and the form was finalized.

\subsection{Gathering and Analyzing Data}

In the interview forms, seven questions were given to each instructor in TTCs. All of the questions were also explained verbally and requested clear answers. Data were examined by the researchers and codes were identified in the analysis. In the reporting period, a "P" letter was assigned to each instructors by quoting directly and named as "P1, P2, P3...". 


\section{Findings}

Quotations, categories, and frequencies from the answers the instructors gave to the question of "What do the students think about writing in Turkish? Please explain." are given in Table 1.

Table 1. Results of Instructors' Opinions about Students' Writing Turkish

\begin{tabular}{|c|c|c|}
\hline Category & $\mathbf{f}$ & Sample Sentences \\
\hline $\begin{array}{l}\text { It is one of the most difficult skill for } \\
\text { students. }\end{array}$ & 11 & $\begin{array}{l}\text { The students, especially in A1 and A2 level, had problem in writing } \\
\text { lessons. Some students thought that it was very difficult to write in this } \\
\text { language because of the mistakes made in writing exams on spelling } \\
\text { the words and the use of suffixes. (P9) }\end{array}$ \\
\hline $\begin{array}{l}\text { They have difficulty in writing due to } \\
\text { using different alphabets. }\end{array}$ & 2 & $\begin{array}{l}\text { They think that Turkish writing skill is very hard. They have difficulty } \\
\text { in writing Turkish due to using different alphabets and, especially, } \\
\text { writing umlaut letters. Syntax can be added to these difficulties besides } \\
\text { Arabic is inflected structurally. (P6) }\end{array}$ \\
\hline $\begin{array}{l}\text { They are willing and eager to write } \\
\text { Turkish. }\end{array}$ & 2 & $\begin{array}{l}\text { Although the students make an effort to write, they sometimes lose } \\
\text { their motivation, because it is one of the hard skills to develop. (P7) }\end{array}$ \\
\hline $\begin{array}{l}\text { The importance of writing skill } \\
\text { cannot be understood. }\end{array}$ & 1 & $\begin{array}{l}\text { Our students are willing to write in Turkish. Writing skill in which all } \\
\text { of the skills should be used is more difficult comparing to others. } \\
\text { Nevertheless, the students don't understand the importance of the skill. } \\
\text { (P8) }\end{array}$ \\
\hline $\begin{array}{l}\text { They have difficulty because of lack } \\
\text { of grammar. }\end{array}$ & 1 & $\begin{array}{l}\text { Generally, they think that it is difficult. They have difficulty, because } \\
\text { writing skill requires vocabulary and grammar. (P3) }\end{array}$ \\
\hline $\begin{array}{l}\text { They have difficulty in writing } \\
\text { umlaut letters. }\end{array}$ & 1 & $\begin{array}{l}\text { They think that Turkish writing skill is too difficult. They have } \\
\text { difficulty in writing Turkish due to difference of alphabets and, } \\
\text { especially umlaut letters. (P6) }\end{array}$ \\
\hline $\begin{array}{l}\text { They have difficulty due to Arabic } \\
\text { syntax and its being inflected. }\end{array}$ & 1 & $\begin{array}{l}\text { They think that Turkish writing skill is very hard. They have difficulty } \\
\text { in writing Turkish due to using different alphabets and especially } \\
\text { writing umlaut letters. Syntax can be added to these problems besides } \\
\text { Arabic is inflected structurally. (P6) }\end{array}$ \\
\hline $\begin{array}{l}\text { They have difficulty in writing } \\
\text { punctuation marks. }\end{array}$ & 1 & $\begin{array}{l}\text { They have a prejudice that Turkish is difficult, because they have } \\
\text { difficulty in writing punctuation, especially, semicolon etc. (P7) }\end{array}$ \\
\hline
\end{tabular}

General view of the instructors according to Table 1 is that Syrian Arabians have prejudice against the education in writing Turkish and they lose motivation because it is a difficult skill for them even if they are willing to acquire this skill. They experience difficulties due to the differences between alphabets, learning umlaut letters and the usage of punctuation marks. In addition, they think that Turkish is a difficult language to learn and they are prejudged due to lack of grammar (suffix-root).

The quotes, categories and frequencies from the answers of the instructors to the question of "Do you have any difficulties while teaching Turkish writing skill? Why?" are given in Table 2.

Table 2. Difficulties the Instructors Experienced While Improving the Students' Writing Skill

\begin{tabular}{|c|c|c|}
\hline Category & f & Sample Sentences \\
\hline $\begin{array}{l}\text { I have difficulty while teaching } \\
\text { writing-skill in Turkish }\end{array}$ & 7 & $\begin{array}{l}\text { I have trouble with especially elementary students. We have difficulty } \\
\text { about the richness and accuracy of grammar usage and the richness of } \\
\text { vocabulary while teaching writing skill. (P9) }\end{array}$ \\
\hline $\begin{array}{l}\text { I do not have any trouble while } \\
\text { teaching writing skill. }\end{array}$ & 4 & $\begin{array}{l}\text { No. Writing is a quite convenient skill for rich material preparation } \\
\text { since writing skill is based on improving expression ideas just like } \\
\text { speaking skill. (P11) }\end{array}$ \\
\hline $\begin{array}{l}\text { Reflecting the differences to writing, } \\
\text { especially articulation between } \\
\text { Turkish and Arabic }\end{array}$ & 1 & $\begin{array}{l}\text { Yes. The students reflecting the articulation differences to writing } \\
\text { between Turkish and Arabic make spelling errors frequently and it is } \\
\text { hard to fix it. (P4) }\end{array}$ \\
\hline $\begin{array}{l}\text { Difficulties related suffix and } \\
\text { functions of suffixes }\end{array}$ & 1 & $\begin{array}{l}\text { I sometimes have trouble. Because the students whose language is } \\
\text { originated from a different language family say that there were lots of } \\
\text { suffixes in Turkish, and that they had difficulty about that. The reasons } \\
\text { such as having lots of suffixes and their various functions could cause } \\
\text { some difficulties some students in writing skill. (P8) }\end{array}$ \\
\hline $\begin{array}{l}\text { Difficulties related to the prejudice } \\
\text { and negative attitudes. }\end{array}$ & 1 & $\begin{array}{l}\text { We have difficulties in breaking the prejudices of the students. Their } \\
\text { negative attitudes prevents them to improve writing skill. (P6) }\end{array}$ \\
\hline $\begin{array}{l}\text { Easiness about the students' } \\
\text { awareness of their own mistakes }\end{array}$ & 1 & $\begin{array}{l}\text { If I make the students be aware of their own mistakes, I don't have any } \\
\text { difficulty. I generally succeed it. Because I get the students to practice } \\
\text { writing and give them feedbacks about their mistakes. I give the } \\
\text { troubled students some extra practices about their problems. (P1) }\end{array}$ \\
\hline
\end{tabular}

According to Table 2, the majority of the instructors experience difficulties while teaching Turkish writing to the students. Rich and agglutinative nature of Turkish language makes this process much more difficult for Syrian Arabian students. In addition, the need for constant repetition of easily forgotten grammatical structures in Turkish for a more 
effective learning discourages the students. The instructors have had difficulty in overcoming students' prejudices against writing education. Due to the negative attitudes of students towards the topics to be learned, it is hard for instructors to provide an effective writing instruction. The answers of the instructors to the question of "What are the mistakes your students make most frequently? What kind of activities do you do to fix these mistakes? Please explain." are shown in Table 3 with the quotes, categories and frequencies.

Table 3. Findings of Difficulties Instructors Participants of Interview Faced While Writing Skill Teaching

\begin{tabular}{|c|c|c|}
\hline Category & $\mathbf{f}$ & Sample Sentences \\
\hline $\begin{array}{l}\text { Difficulties encountered in writing } \\
\text { umlaut vowels. }\end{array}$ & 3 & $\begin{array}{l}\text { The problem we encountered mostly is that they confuse the letters of } \\
\text { " } 1>\mathrm{i}, \mathrm{o}>\ddot{\mathrm{o}}, \mathrm{u}>\ddot{\mathrm{u}} \text { ". We overcome this mistake by getting them to use the } \\
\text { words with these letters more frequently and by correcting } \\
\text { articulations. (P2) }\end{array}$ \\
\hline $\begin{array}{l}\text { Difficulties encountered in usage of } \\
\text { vowels. }\end{array}$ & 3 & $\begin{array}{l}\text { They have problems in the usages of lower and uppercase vowels, } \\
\text { punctuations and composing paragraphs. I carry out process-based } \\
\text { writing activities. (P7) }\end{array}$ \\
\hline $\begin{array}{l}\text { Generally, failing to write the suffixes } \\
\text { and specifically, case suffixes }\end{array}$ & 3 & $\begin{array}{l}\text { They have difficulties in the usage of suffixes. They try to write as they } \\
\text { speak. In order to fix these problems, I note the mistyped words at the } \\
\text { end of every writing assignment. I ask the words again. This gives me } \\
\text { an opportunity to revise grammar and see their mistakes. (P10) }\end{array}$ \\
\hline $\begin{array}{l}\text { the titles are forgotten while writing a } \\
\text { text. }\end{array}$ & 1 & $\begin{array}{l}\text { Students forget to write titles for the texts. Some students have trouble } \\
\text { with understanding the topic given. Some of them make mistake in } \\
\text { establishing connect between sentences or paragraphs. We prefer } \\
\text { pointing out the mistakes in the texts and explaining the corrections } \\
\text { one by one and then getting them to write again. (P9) }\end{array}$ \\
\hline $\begin{array}{l}\text { Failing to understand the phonetic } \\
\text { change makes writing skill difficult. }\end{array}$ & 1 & $\begin{array}{l}\text { (i-1-u-ü) sounds are big problem for them. Phonetic change is the big } \\
\text { problem as well. (çiçek-i, ara-yor...). Grammar rules (phrases and } \\
\text { especially accusative case suffix) cannot be grasped easily. I always } \\
\text { correct their mistakes about these rules. I give homework every day, } \\
\text { and then they write it on the board. (P3) }\end{array}$ \\
\hline $\begin{array}{l}\text { Problems related syntax mistakes } \\
\text { and their solutions }\end{array}$ & 1 & $\begin{array}{l}\text { Mistakes students made mostly while writing Turkish are related to the } \\
\text { grammar structures. This is followed with syntax mistakes. I try to } \\
\text { overcome these mistakes by giving lessons for their general problems, } \\
\text { and bringing some practices and activities. (P1) }\end{array}$ \\
\hline $\begin{array}{l}\text { The problems related to writing } \\
\text { letters of "-ç,-ş" and "-il" and their } \\
\text { solutions }\end{array}$ & 1 & $\begin{array}{l}\text { They mistype letter "Ç" because there is no a 'Ç' letter in the Arabic } \\
\text { alphabet. They write "ş' letter as 'sh'. Besides, they may write "i" letter } \\
\text { as "e" at the end of words. I help the students by pointing out their } \\
\text { mistakes and fixing them on the exam papers. (P4) }\end{array}$ \\
\hline $\begin{array}{l}\text { The problem of inability to connect } \\
\text { sentences with convenient } \\
\text { conjunctions and its solution }\end{array}$ & 1 & $\begin{array}{l}\text { To write words regardless of caring lower-uppercase, consonants or } \\
\text { vowels, not able to connect sentences with convenient conjunctions, to } \\
\text { write suffixes not considering the phonetic change are of the major } \\
\text { problems. We reflect the students' writings to the board by the } \\
\text { projection and fix the mistakes together in order to overcome these } \\
\text { problems. We also work on good writing samples starting from } \\
\text { sentences, paragraphs and texts. (P6) }\end{array}$ \\
\hline
\end{tabular}

According to Table 3, most of the instructors experience problems in teaching the students writing vowels. Writing umlauts constitutes a problem for Arabian students. This mistake is followed by writing suffixes, syntax and phonetic changes. Also, since they cannot get used to the alphabet at very beginning of teaching, it leads them to make mistakes and deficiency in writing of consonants like "-ç,-ş,-i" and lower and uppercase, apart from mistakes in writing vowels.

The answers of the instructors to the question of "What are the methods and techniques you use to improve your students Turkish writing skill? And what are the problems you faced while using these methods and techniques?" are shown in Table 4. with the quotes, categories and frequencies. 
Table 4. The Methods the Instructors Used to Improve Students' Turkish Writing Skills and the Findings Related to the Problems Experienced While Using These Methods

\begin{tabular}{|c|c|c|}
\hline Category & $\mathbf{f}$ & Sample Sentences \\
\hline $\begin{array}{l}\text { Using dictation method to improve } \\
\text { students' Turkish writing skill }\end{array}$ & 7 & $\begin{array}{l}\text { We give examples in sampling method. We make them write } \\
\text { compositions. Thus, we get an idea about how they can improve and } \\
\text { whether they use grammar rules properly. When we ask them to write a } \\
\text { composition, we move from not only certain topics but also some } \\
\text { materials such as pictures and cartoons. Also, we make dictation and } \\
\text { control them. (P8) }\end{array}$ \\
\hline $\begin{array}{l}\text { Benefiting from pictures, tables, } \\
\text { smart boards and schemas in writing } \\
\text { education. }\end{array}$ & 4 & $\begin{array}{l}\text { We do exercises of dictation and simple writing sentences in a basic } \\
\text { level. We benefit from tables, pictures and schemas. Then, we use the } \\
\text { methods of summarizing, completing, and controlled writing. (P5) }\end{array}$ \\
\hline $\begin{array}{l}\text { Improving students' Turkish writing } \\
\text { skills with process-based writing }\end{array}$ & 2 & $\begin{array}{l}\text { I use practices of process-based writing (preparation, planning, drawing } \\
\text { an outline, writing with editing, sharing). I show each step on the smart } \\
\text { board how to practice because the students don't know this method } \\
\text { beforehand. They have problems in the stage of writing with editing. I } \\
\text { try to overcome this problem with practices. (P6) }\end{array}$ \\
\hline $\begin{array}{l}\text { Educating Turkish writing according } \\
\text { to their levels and readiness }\end{array}$ & 2 & $\begin{array}{l}\text { The students are generally given a sample case and asked to write in a } \\
\text { form suitable with their level in the writing lessons. Additionally, } \\
\text { writing activities are practiced such as dialog completion and story } \\
\text { (event) completion. My biggest problem for this skill is that lesson } \\
\text { period is not enough for completing writing activity, controlling and } \\
\text { then giving feedback to the students. (P11) }\end{array}$ \\
\hline $\begin{array}{l}\text { Using other methods in teaching } \\
\text { writing in Turkish }\end{array}$ & 1 & $\begin{array}{l}\text { I use the methods such as process-based writing, controlled writing, } \\
\text { completing the text, guessing, creative writing, writing as a group, } \\
\text { deduction etc. If the students are taught these methods, we face not so } \\
\text { many problems. (P7) }\end{array}$ \\
\hline $\begin{array}{l}\text { Problems in writing long words with } \\
\text { suffixes }\end{array}$ & 1 & $\begin{array}{l}\text { Dictation could be practiced. They have problem in writing long words } \\
\text { due to the articulation or because Turkish is an agglutinating language. } \\
\text { (P4) }\end{array}$ \\
\hline
\end{tabular}

According to Table 4, the technique the instructors commonly used is dictation while practicing Turkish writing skill to Syrian Arabian students. Teachers should use dictation of suitable texts both reinforcing the usage of punctuation marks and teaching new words and introducing cultural values. Dictation method will enable to reinforce and understand the spelling rules (Tekşan, 2010). Dictation is technique used basically for listening and writing skill training, but dictation practice offers students to do many activities at the same time. Dictation is effective in all aspects of language ranging from grammar learning, enhancing vocabulary, improving the understanding ability to syntax while listening and writing skills is being practiced (Bozkurt, Bülbül \& Demir, 2014).

Another important point in writing education is that instructors use activities such as controlled writing, guessing, creative writing, text (dialog and event) completion and writing as a group with process-based writing. Instructors also benefitted from pictures and cartoons to elaborate the text in order to reinforce the understanding of the students. However, instructors complained about the lack of these kinds of materials that can be used in writing education. Another problem they reported is the inadequacy of the lesson time. They mentioned that lesson time is not enough to give valuable feedback to the students about their writing.

The answers of the instructors to the question of "How do you evaluate the writing activities you preferred in your classes in terms of cultural transfer principle? Please explain." are shown in Table 5 with the given quotes, categories and frequencies. 
Table 5. The Findings about the Cultural Transfer in Writing Education to Syrian Students According to the Instructors' Evaluation.

\begin{tabular}{|c|c|c|}
\hline Category & $\mathbf{f}$ & Sample Sentences \\
\hline $\begin{array}{l}\text { I prefer giving texts related to } \\
\text { Turkish culture to the students } \\
\text { taught Turkish writing as language } \\
\text { transfer naturally serves to cultural } \\
\text { transfer. }\end{array}$ & 7 & $\begin{array}{l}\text { It is valid for all types of skills. The language teaching itself also } \\
\text { includes cultural transfer. We reinforce it with the themes used in } \\
\text { writing activities. Students realize the difference better between his } \\
\text { cultures and the learned one, especially, when they are required a } \\
\text { comparative writing. (P5) }\end{array}$ \\
\hline $\begin{array}{l}\text { The students' participation to writing } \\
\text { education using their own cultural } \\
\text { elements }\end{array}$ & 5 & $\begin{array}{l}\text { We pay attention that writing activities reflect our culture. However, } \\
\text { while introducing our culture, we try to give an opportunity to the } \\
\text { students from other cultures to introduce their own culture. Also, we try } \\
\text { to get to know other cultures and give respect to these cultures as a } \\
\text { principle. For instance, we, firstly, introduce our traditions in festals, } \\
\text { and then we ask them to write about how the festals are celebrated in } \\
\text { their culture. (P8) }\end{array}$ \\
\hline $\begin{array}{l}\text { Writing education in terms of the } \\
\text { themes used in our culture }\end{array}$ & 2 & $\begin{array}{l}\text { I use motives from Turkish culture while determining themes of writing } \\
\text { activities since language is a composer and carrier of culture. I present } \\
\text { samples from quotes of Turkish elders primarily Yunus Emre and } \\
\text { Mevlana in using strategies of developing ideas. (P6) }\end{array}$ \\
\hline $\begin{array}{l}\text { The importance of cultural transfer } \\
\text { in terms of students' getting an idea } \\
\text { about other cultures }\end{array}$ & 1 & $\begin{array}{l}\text { I think writing skill is really beneficial from the point of students' } \\
\text { getting to know each other and getting an idea about one another's } \\
\text { cultures. Because it is important that a student is calm and warm to be } \\
\text { able to express himself and his own culture. The students could be } \\
\text { excited, or be ashamed and thus expression problems may occur in } \\
\text { speaking classes. This problem is faced not much in writing and the } \\
\text { student can express more strongly. (P11) }\end{array}$ \\
\hline
\end{tabular}

According to Table 5, the instructors benefit from the cultural transfer while improving Syrian Arabians' writing skill. Cultural transfer is that cultural elements of a nation is told, taught and transferred to new generations in its simplest definition (Uyar, 2007). Teachers make cultural transfer by using elements both from Turkish culture and their own culture in order to make students express themselves easily. Besides, teachers use activities that may provide neutral cultural comparisons between the culture students have and are learning in order them to develop cultural awareness about the language they are learning, allowing the students to adapt to Turkish life.

Since language teaching includes cultural transfer in its nature, in Turkish teaching it is very important to give texts containing elements of Turkish culture in order students to adapt to the language fast and get to know the country they live in. Language is a cultural transmitter. That's why culture is the most important factor in language teaching (Barın, 2006). Language facilitates the communication between people, so this shows it has also a social function (Özbay \& Karakuş-Tayşi, 2011). The instructors prefer the texts intended to introduce Turkish culture, so that these texts could help to connect people friendly. In these texts, the instructors teach the motives of Turkish culture like Mevlana and Yunus Emre. Other texts which can be used in the process of cultural transfer are the masterworks of other greatthinkers. Because, it is the authors and thinkers who use the language of that nation best. The well-established and correct sentences in the works of these authors and thinkers will set an example for students (Tekşan, 2010). Also instructors provide students a comfortable learning environment in which they feel secure by creating a respectful atmosphere to both cultures by using the appropriate texts including neutral comparisons of the cultures.

The answers of instructors to the question of "What are the measurement and evaluation studies you used to determine levels of writing skill acquisition and development?" are shown in Table 6. with the given quotes, categories and frequencies. 
Table 6. Results about the Measurement and Evaluation Studies of the Instructors Used to Determine Levels of Writing Skill Acquisition and Development

\begin{tabular}{lll}
\hline Category f & Sample Sentences \\
\hline $\begin{array}{l}\text { Measurement and evaluation of } \\
\text { writing education } \\
\text { homeworks and exams }\end{array}$ & 4 & $\begin{array}{l}\text { It is asked them to write appropriately according to their level about a } \\
\text { topic or a case given for writing skill in class-change exams. Apart } \\
\text { from the exams, mini quizzes and writing activities are conducted in } \\
\text { order to improve the skill and correct the mistakes. (P11) } \\
\text { We measure that how much the students apply the rules by preparing } \\
\text { exercises about the usage of spelling and punctuation marks. We } \\
\text { determine that how much they learn by preparing exercises about the } \\
\text { usage of suffixes. We measure whether they write properly what they } \\
\text { hear by doing dictation. (P8) }\end{array}$ \\
$\begin{array}{l}\text { We get an idea about the design of the paper and paragraphs and how } \\
\text { much they apply their knowledge while writing a composition. (P8) }\end{array}$
\end{tabular}

learned according to the design of paper and order.

Evaluating writing skill by using 1 We give homework for the weekends and evaluate them. We prepared a writing scale

Measuring the process of writing education according to grade charts

1 Understanding the topic $\rightarrow$ has the student comprehended the topic given? Did he understand what to do and report it with correct examples as in the paragraph form? These criteria primarily take place in our grade chart. (Our written evaluation chart is prepared according to 100 point scale). (P9)

After the Criteria of the 1 Improvement level of writing skill is pursued stage by stage. Writing measurement and evaluation scale text comes after writing sentence and paragraph. In this process, the criteria in the measurement and evaluation scale are explained one by are explained to students, grading is implemented.

The measurement of writing skill one and points are given to the students. (P6)

with the methods of peer evaluation Sometimes, measurement and evaluation is conducted via peer evaluation and self-evaluation in the class. (P6)

and self-evaluation

The measurement of writing skill by $\quad 1 \quad$ We don't use a scale for that. (P5) the official educators.

According to Table 6, the primary drawback in Turkish education to foreigners during the improvement of writing skill is measurement and evaluation. There are some serious problems for TTCs since there is not a standard scale in evaluation of writing skill education and each teacher prepares different scales for the activities. To educators, the most important scales of writing activities are the exams they did and the homework and the tasks they gave. The instructors using dictation and composition activities for teaching writing skill complain that they have no criterion for evaluating the works of the students. Furthermore, there are also instructors saying they don't use any scale at all. The scale used by instructors most commonly is the evaluation chart of written expression. It is supported that the criteria in this scale must change based on the mother tongue of the students. Apart from that, teachers use peer evaluation and self-evaluation methods in writing classes.

The answers of the instructors to the question of "Do you find teachers who give Turkish education to foreigners sufficient in terms of improving basic language skills? How do you evaluate yourself in these terms? " are shown in Table 7 with the given quotes, categories and frequencies. 
Table 7. Results about Whether the Instructors Giving Turkish Education to Foreigners Find Their Colleagues and Themselves Sufficient In Terms of Improving Language Basic Skills

\begin{tabular}{lll}
\hline Category & f & Sample Sentences \\
\hline The view that educators who is not & 4 & Teaching Turkish to foreigners is a new but fast-growing field in
\end{tabular}
expert in their field give these skills Turkey. There is few expert instructors in this field. Expert instructors and that an expert is necessary are needed now. That the people working in this field have not much experience in teaching Turkish to foreigners causes some problems. I graduated from university in 2003 and I have been teaching Turkish to foreigners since my graduation. I find myself sufficient in improving basic skills. I try to improve myself in the points I find or feel insufficient and to overcome my inadequacies. (P1)

The view that there are lots of points which educators improve themselves

I find myself sufficient and successful

The view that educators will improve with experiences

I don't find myself sufficient.

The need to work in making educators successful.

The view that educators teaching Turkish to foreigners have limited knowledge about this field
4 Firstly, the field is rather new and secondly what we try to do here seems just as an amateur job, after I saw the education of the teachers I met in TTC in Ankara. I taught Turkish to Turkish citizen for 4 years. I have been teaching to foreigners for 2 years. The latter one is seriously different thing. I have lots of things to learn. (P5)

3 I find educators successful when it is evaluated in the frame of our university and neighbor universities. But we suffer from available resources and instant material. Alternatives of the coursebooks should be increased. Also, coursebooks, materials (vocabulary posters, games, vocabulary cards, pictures etc.) should be prepared. (P11)

3 There are of course competent people in the field but I don't think that all educators are qualified enough because this field is a new one. However, each year being spent in the place of this job is an experience. I believe that I have had my best, but I have lots of things to learn just like everyone. (P8)

2 Since not all of the educators are field experts or experienced on this field long enough, they are not qualified sufficiently. I don't find myself sufficient but think that I am on the way of being an expert. (P6) I think educators should improve themselves. We see that the attendance to different activities and studies abroad is not enough. There is a considerable need of comparative studies. One of the important points which will enable educators to improve their professional skills is making cooperative studies in collaboration with the researchers using new method and techniques. (P9)

1 Unfortunately, the educators teaching Turkish to foreigners have limited theoretical knowledge about this field. Master programs about this field have recently been opened. I , as a person who is coming from the place of this job and doing doctorate in this field, think that there are a lot of topics to work on and a lot of points we should improve ourselves in. (P4)

According to Table 7, the most important topic which the instructors in TTCs complained about teaching Turkish to foreigners was that teachers are not experts in this field. However, they thought that even being not an expert causes some problems in teaching, the experiences gained in classes while teaching will make the instructors more experienced and in time they will become experts. In accordance with the same idea, teachers could educate themselves about the topics in which they find themselves insufficient. The educators who find themselves insufficient in this field understand by making self-evaluation that there are lots of points they should improve themselves in the way of being proper teacher. On the other hand, the educators who find themselves sufficient in this field underline the lack of materials used in language education. Another view which will enable educators to improve their professional skills is making collaborative studies with the experts of the field in topics such as method and technique. It can be concluded that teaching Turkish to foreigners is not conducted by experts, highlighting the pressing need for experts in teaching Turkish as a foreign language.

\section{Discussion}

This study focuses on the instructors' ideas working in Turkish teaching centers about Turkish writing skill teaching to Syrian Arabians. In this context, the methods and techniques they used, the difficulties they faced and the solutions they suggest to overcome these problems were investigated. In addition, the issues of cultural transfer and writing assessment were also investigated. For instructors, it can be said that the most difficult skill is writing while teaching the language skills to Syrian Arabian students. Articulation and alphabet differences seem the basic reasons causing difficulties in teaching this skill. Even though students are generally willing to learn Turkish language, their attitudes towards writing education make improvement of them at this skill more difficult. Instructors practice dictation and try to give feedback to students in order to overcome the problems that the students are experiencing while learning the writing skill. It can be stated that the method mostly used in teaching writing, is dictation. The instructors stated that 
they had difficulty in teaching writing particularly in A1 and A2 levels, but in upper levels, according to the instructors, the context makes the students more comfortable and motivated and writing skill becomes easier to learn since the prejudices of students against writing skill are removed. Most of the instructors reported that they had difficulty in improving writing skill of their students. In this process, one of the problems they faced commonly is the difficulty in teaching the writing of umlaut letters and punctuation marks. Another frequent problem is that the suffixes have a lot of roles so the students have problem about suffixes. Students have failures in understanding the phonetic change. Since they cannot understand the phonetic change, they could make mistakes in writing words. That some letters do not exist in Arabic or letters are perceived by students as different letters also cause some problems. For instance, that "ç" letter does not exist in their alphabet causes problems in this sound and they have difficulty in writing it. Students may write "s" letter as "sh". Syrian students may write "e" letter instead of "i" letter in the Turkish words due to the similarity of the sounds. Another problem is that students cannot connect sentences by using conjunctions, meaning that they experience difficulties in combining two or more ideas.

The inadequacy of appropriate materials for teaching Turkish, particularly writing, is another problem that the instructors complained about. In fact, scholars in the field of language teaching considered that the coursebooks have an important role in language teaching (McGrath, 2006; Riazi, 2003). For this reason, development of materials for teaching Turkish writing to foreigners is an important issue. In this context, coursebooks, the most widely used language teaching materials, should give importance to writing activities and tasks that may help the instructors. In these materials, cultural transfer should be taken into account since "In the process of any kind of study, research and program preparation performed for language education, the connection of the language with society and naturally with culture should be taken into consideration" (Baş, 2011: 115). The instructors believing that writing education should include cultural transfer in its own nature generally use Turkish authors and thinkers like Yunus Emre and Mevlana as the themes in writing education. "Writing is a skill used in many fields ranging from people's daily lives to sharing their ideas in common" (Tok, 2013: 251). In this respect, the instructors teach the students about Turkish culture thus making their lives easier; further, they strengthen their relationships with the students by using some elements from the students' culture. In other words, comparisons between the target culture and home culture contribute to the cultural awareness of students. However, while creating opportunities for students to make comparisons between the cultures, the materials, coursebooks, particularly "include texts comparing the target culture elements without being critical to those of elements belonging to the learners' own culture.... in order to avoid describing one culture as superior to the other one or vice versa" (Başal \& Aytan, 2014: 333).

\section{Conclusion}

As a result, the instructors stated that they had difficulty in teaching Turkish writing to Syrian Arabians. The reasons for difficulties are attributed to lack of appropriate instructional materials and scales for writing assessment. For the instructors, the feedback which can definitely improve students' writing skill cannot be given adequately to the students due to the inadequate class time, causing another problem in teaching Turkish writing skill. Materials including tables, pictures, smart boards and schemas which may ease the teaching of Turkish writing are not adequate and this also causes problems in teaching writing according to the instructors. Based on the results of the study, it can be concluded that there is a lack of experts in teaching Turkish language as a foreign language. This deficiency is one of the most important problems in teaching writing skill as well as other skills. For this reason, following suggestions can be put forward for teaching Turkish writing to Syrian Arabians based on the results of the current study:

- There is a huge need for training instructors on the subject of teaching Turkish writing to Syrian Arabians. It is considered that more qualified instructors in teaching Turkish as a foreign language can contribute to more effective teaching of Turkish as a foreign language.

- Most of the instructors find themselves insufficient in teaching Turkish as a foreign language. In-service training courses should be carried out based on the needs of the instructors, allowing them to be more qualified in teaching Turkish to foreigners. In these courses, instructors should be equipped with new methods and techniques that can be used in teaching Turkish writing.

- Writing tasks and activities should be linked with daily life, allowing students to make connections between the language they learn and the culture the country has. In addition, the texts to be used in teaching Turkish should include cultural elements of the target language and the students should be given opportunities to compare their own culture and the target culture. These comparisons should be made in a neutral manner.

- Writing assessment is an important aspect in evaluating the students' performances. However, there is a lack of assessment scales for evaluating the written works of students. Therefore, sound and practical assessment scales that can be used in the evaluation of students' written works should be developed. These scales can enable the instructors to determine the weaknesses in students' writings and to give the students more appropriate feedback. 
- Instructors in this study think that teaching of suffixes, umlaut letters and conjunctions are problematic areas while teaching writing skills to Arabians from Syria particularly in the lower levels. For these reasons studies should be conducted to find effective ways to teach suffixes, umlaut letters and conjunctions.

- There are not enough materials to be used in teaching writing to the students. Therefore, coursebooks and other materials that give particular attention to writing skill by including tasks, activities and sections should be designed and developed.

\section{References}

Barın, E. (2006). The importance of written narration and dictation in teaching Turkish to Turk children in abroad. Belleten, 2006-I, 21-32.

Baş, B. (2011). A view to speaking and writing skills as part of the relations between oral and written culture. Pamukkale University Journal of Education, 29, 109-117.

Başal, A., \& Aytan, T. (2014). Investigation of cultural elements in coursebooks developed for teaching Turkish as a foreign language. International Online Journal of Educational Sciences, 6(2), 328-336. http://dx.doi.org/10.15345/iojes.2014.02.007

Bozkurt, B., Bülbül F., \& Demir, H. (2014). Dictation and teaching Turkish as a foreign language. Turkish Studies International Periodical for the Languages, Literature and History of Turkish or Turkic, 9(6), 159-173

Göçer, A. (2010). Writing education in Turkish teaching. The Journal of International Social Research, 3(12), $178-195$.

McGrath, I. (2006). Teachers' and learners' images for coursebooks. ELT Journal, 60(2), 171-180. http://dx.doi.org/10.1093/elt/cci104

Özbay, M. (2014). Writing education. Ankara: Pegem Academy.

Özbay, M., \& Karakuş-Tayşi, E. (2011). The importance of Dede Korkut Stories in terms of Turkish language education and value transfer. Pegem Journal of Education and Instruction, 1(1), 22-31.

Özdemir, M. (2011). Qualitative data analysis: A study on methodology problem in social sciences. Eskişehir Osmangazi University Journal of Social Sciences, 11(1), 323-343.

Riazi, A. M. (2003). What do textbook evaluation schemes tell us? A study of the textbook evaluation schemes of three decades. Anthology Series Seameo Regional Language Centre, 44, 52-69.

Tekşan, K. (2010). The role of written expression in culture transfer. TÜBAR (XXVII), 595-600.

Tok, M. (2013). Evaluation of writing activities in coursebooks of teaching Turkish to foreigners. Uşak University Journal of Social Sciences, 6(1), 249-279.

Ungan, S. (2007). Development and importance of writing skills. Erciyes University Journal of Social Sciences Institute, $23,461-472$.

Uyar, Y. (2010). Cultural transfer in Turkish teaching and develop cultural identity. Gazi University Institute of Educational Sciences, Department of Turkish Language Teaching (Master's Thesis).

Yıldırım, A. \& Şimşek, H. (2005). Qualitative research method in social sciences. Ankara: Seçkin Press.

\section{$(\mathrm{Cc}) \mathrm{BY}$}

This work is licensed under a Creative Commons Attribution 3.0 License. 